\title{
The Influence of Changes of Islam and Politics Relations in 20th Century on the Strategy of Belt and Road
}

\author{
Yan $\mathrm{Li}^{1}$ \\ ${ }^{1}$ School of Humanities, China University of Political Science and Law, Beijing 100088, China \\ Correspondence: Yan Li, School of Humanities, China University of Political Science and Law, Beijing 100088, China.
}

Received: December 12, 2017

Accepted: January 15, $2018 \quad$ Available online: January 23, 2018

doi:10.11114/ijsss.v6i2.2945

URL: https://doi.org/10.11114/ijsss.v6i2.2945

\begin{abstract}
In the early twentieth century, with the independence of the Islamic nations, the religion of Islam withdrew from the traditional unification of religion and state (caesaropapism) to private life. The secularization of Islam has taken its course and its political characteristics have weakened. In the process of globalization of economy, politics and culture, the development of all countries became uneven and imbalanced. In the mid-to-late 20th century, it turned out that the secularization and modernization advocated by the nationalist had failed to effectively solve the development problems which the Muslim countries faced. This made Islam continue to strengthen its position in both domestic and international political life of Muslim countries. The traditional religious identity has become a powerful tool for the domestic cohesion and international fight against power. The analysis of the changes of Islamic religion and politics relations in 20th century can help to understand and reflect on the frequent ethnic and international conflicts in the world at present. Such changes will also affect the development strategy of China's Belt and Road initiative.
\end{abstract}

Keywords: Islam, political nature, nationalism, modernization, globalization

\section{Introduction}

Influenced by nationalism, socialism and Hegel's philosophy in the late 19thcentury, the religion of Islam in many countries generally drew from the national public sphere and became the personal spirits in the early 20th century. Later in the 20thcentury Islam quickly returned to the realm of public life and affected the political life in many countries, both internally and internationally. As one of the three major religions in the world, Islam, with about 1.2 billion followers, is mainly distributed in about 50 countries in Asia and Africa. Under the background of the 20th century, the relationship between Islam and politics in Asia presented the trend of uneven strength in different stages. Sometimes secularism and nationalism inscribed religions into the imprint of modern politics, and sometimes they made fundamentalist breakthroughs in the political boundaries of countries.- Islamic religious identity formation can cross borders and unite social forces.

\section{Relations between Islam and Politic in Muslim Countries of Asia in the 20th Century}

\subsection{Weak Political Nature of Islam in the Muslim Countries in the Early 20th Century}

At the beginning of the 20th century, most Muslim countries were under European control. Muslim countries carried out the decolonization resistance movement on the call of the nationalists who were dominated by the intellectual elites. The traditional Muslim country, unified by the state and the church, has brought the modernization of the country and society through the reform of religions and the knowledge-based social reforms in order to realize state and social modernization. Islam and its organizations have lost their past power in the political, cultural and legal fields, but they continued in their daily lives and are constantly trying to adapt to changes in society. An internal Isalm reform movement appeared in Indonesia in South Asia in the early 20thcentury, aimed at propagating mysticism and asceticism in traditional Islam, opposing mysterious religious ceremonies and promoting the day-to-day religious life. This movement was called the "Dawa Movement".

The 20thcentury was an era when nationalism and religion were intertwined. The secularization of Muslim countries was mainly driven by the nationalists represented by intellectual elites. Both nationalism and religion emphasized loyalty. The former, as a collection of fuzzy emotions, was the identification and loyalty of a nation or country of a particular order and law, while the latter emphasized loyalty to the existing immaterial sacredness and its power. The 
differences between the two loyalists made them contradictory to each other, but when they faced with common pressures, they can support each other. This transformation of Islamic doctrine has led to a rise in the religious-based nationalist movement, which has become independent of European colonial rule. At the beginning of the 20th century, Turkish nationalism in the Near East rose after the sunset of the Ottoman Empire and carried out reforms aimed at strengthening the separation of religions and state. Although the Constitution in 1908 still stipulated that Islam was a state religion, it also stipulated that the king must swear to abide by the Constitution. The ministerial meeting was responsible to the parliament and the authority of the secular court was strengthened. Turkey's Family Law, promulgated in 1917, made marriage a secular relationship and increased women's educational opportunities. With the suspension of the last two religious schools in Turkey in 1932 and the suspension of the theological college at Istanbul University in 1933, religion was mostly dropped out of education. Although the Turkish reforms of the early 20th century did not become fully secularized countries, they gave birth to the "bicultural" phenomenon in which the secular and religious cultures coexist in the politics, judiciation and education. Turkish secularization relied mainly on top-down reforms and state laws to enforce, so it was not thorough, and laid the groundwork for the subsequent Islamic renaissance in politics. In a bid to oppose the Hindu dominion of the National Assembly, the Far East's Muslim formed the Muslim Alliance headed by Ali Jinnah in 1906. In the 1930s, Ali Jinnah promoted the doctrine of Islam as largely a politicized religion and proposed the formation of an independent Muslim nation. This eventually led to the establishment of a Pakistani nation that embodies nationalism and Islam.

The Islamic modernization movement of the early 20th century focused on "de-mystifying" Islam and its secular life, focused on the coordination of religion with the daily life of the people, emphasized the orthodoxy of religious devotion and scripture, and advocated the thrifty and anti-materialistic anti-materialism. Therefore, Islam in this period appeared weakly political nature compared to the other periods of this century.

\subsection{Islamization of Domestic Politics in Muslim Countries in the Middle and Late 20th Century}

Most of the nations that were independent after the Second World War split under the three major banners of Christianity, communism and Islam. The anti-mainstream culture prevailing after the war promoted the spread of mysticism through popular culture and laid the spiritual foundation for the religious revival represented by fundamentalism. However, the rapid development of modernization was the main reason for the revival and politicization of Islam. After the national independence, the Muslim countries have embarked on a path of modernization (mainly Westernization), and the role of capital in society and distribution of resources has brought about profound changes in the social structure of these Islamic countries. The development of modernization has caused drastic changes in the social structure of the Muslim countries. The most remarkable changes were the rural population flocking to cities. As the same time, handicraftsmen and the small merchants were bankrupt in large numbers. The rural population pouring into the cities was in the miserable situation. The small property owners and small businessmen who had been bankrupt were under intense market competition became dissatisfied with the current policies. Under these circumstances, Islam would naturally become a tool for them to seek spiritual comfort as well as political and economic benefits. None nationalism could provide the public with the same kind of spiritual comfort as religious comfort did. In addition, the two devastating world wars and the de vastation of colonialism, imperialism and industrialization have exposed the flaws of secularism and nationalism. Therefore, unfavorable social, political and economic factors, such as poverty, underdevelopment, unemployment, political corruption, injustice and lack of channels for political participation, have stimulated the intensification of the politicization of Islam. Islam has re-established itself from personal life to public life, from the culture to politics, from domestic to international.

The frustrated nation-state in the process of modernization has sought to rejuvenate its glory through the traditional theocratic society. Firstly, this return was primarily reflected in the more stringent demands on the religious symbols of the Muslim body. The body is one of the explicit extrinsic elements of identity, and it is a window through which an individual views himself and others as the same time others view the individual. Forgetting the body once was the target of many religious practices. As a marker of identity, the body is more obvious and intuitive than other factors. Therefore, different religious beliefs also have significant physical distinction. Muslim hats or headscarves emphasize the difference of the body with non-Muslims, but also emphasize the basic identity and the distinction with others. The physical characteristics of religious identities are extended to culture and system in various ways. Secondly, it is reflected in conservative religious ideas and religious organizations gradually becoming powerful tools in the power competition of Muslim countries. After the 1970s, the Islamic revival was closely linked with the political turmoil in Turkey. All the parties in the country used their power to promote the growth of religious elements. When Turkey plunged into a grave anarchy in 1980, the National Liberation Party held a religious rally in Konya, calling for opposition to secularism and for establishing Islam as a state religion. The military coup of 1980 led to a further rise in the Islamic elements in Turkey's political life. After the revolutionary coup in 1979, Iran demonized the West while it politicized Islam and continued its hatred of colonialism and imperialism in the West to the state and religious life. 
Since then, fundamentalism has become the mainstream of religious movements in most Islamic countries such as Algeria, Sudan, Saudi Arabia, Egypt and Jordan. Most of the independent countries of the mid-20th century did not bring about an increase in material life. In fact, most people found it hard to meet and maintain their day-life need, so they transferred to religion and got spiritual comfort. They influenced domestic and international political life by participating in various Islamic organizations. The return of sub-materialism and spiritual to Islam has gradually brought some Muslim countries to be religious and have once again become the religious theocratic state with the integration of politics and religion. In this period, Islam not only provided people with the spiritual comfort and care that government could not provide, but also became a powerful weapon of religious leaders in politics. Thus, the relationship between Islam and politics has been more closely, and the trend of politicization has become increasingly prominent.

\subsection{International Politics in Late Twentieth Century Influenced by the Pan-Islamist Movement}

The trend toward the politicization of Islam in Muslim countries from the late 20thcentury after 1980 has spread from domestic to international politics. The signs that Islam began to intervene in international politics were that Pan-Islamic international political organizations have been established. Such organizations call for strengthening Islamic solidarity based on common beliefs and common interests, and making a voice to speak out. The potential political implication of this "Islamic State" (Shari'a) was the recognition that nationalism was not enough to serve as the banner of the alliance of Islamic countries. To strengthen solidarity, mutual assistance and cooperation, Muslin must rely on more authoritative and more cohesion of Islamic faith. Most Islamic intellectuals are devoted to advocating the concept of Europe, emphasizing the role of secularism and law in social control as a response to fundamentalism, believing that in the age of consciousness, democracy and human rights, the public has the right to participate public affairs, so people would not been imposed and they could decide the model of the country governance. In addition, the interaction among Islamic countries were especially complicated in the Middle East. Under the impact of the Islamic Renaissance, three major changes have taken place in the political relations among the Middle East countries: the rise of Islamic politics; the spread of traditional religious and political ideas; and the go vernments of various countries competing for the use of Islam to enhance political legitimacy. The Islamic elements were highlighted in the war between Egypt and Saudi Arabia, the Middle East war, the Iran-Iraq war, the Iranian export revolution and the Middle East terrorism, etc. Since World War II, so far, the ongoing war between Arab countries and Israel has become the one of major sources of turmoil in the Middle East. Conflicts between Islamic countries and Western Christian nations have deepened. Iran, Afghanistan and Sudan are the three countries in the world in which fundamentalist forces are in power. Fundamentalist movements tend to combine religion and terrorist activities, leading to a growing violence in the world. In recent years, extreme Islamic organizations, in the name of religion, have made many explosions and terrorist attacks in many large western cities, seriously threatening the fundamental security of western countries and even the international community.

\section{The Influence and Reflection of the Relationship between Religion and State in the Muslim Countries in the 20th Century}

\subsection{Political Islam has Become the Concentrated Manifestation of the Politicization of Islam in the Second Half of the 20th Century}

The starting point of political ideology of Islam was a realistic social problem whose goal was to establish Umma and to change the position of Muslim society in the political, economic and cultural power structure of the world. Purifying faith is the method and tool of "solving" the realistic problems. Overthrowing the present regime and the re-establishment of social justice in accordance with Sharia, were the prerequisite and guarantee of pure faith. Therefore, they were the most immediate and urgent requirements. This kind of position of treating the nature of the regime or the social order as its top priority was the key to distinguishing the political ideology of Islam from the Islamic religious movement. Political Islam in all countries included religious intolerance and highlights the role of religion in politics. Religious intolerance manifested itself as follows: Citing the Code, establishing the scale of "true Islam" to measure Muslim individuals and society. Highlighting the political manifestations of Islam manifested itself as follows: emphasizing the political environment that is closely related to personal beliefs; the specific political environment as the key to prevent or ensure the Islamic faith; all problems of the real society are attributed to "deviate from the right path" or "deviate from the real Islamic faith", emphasizing that "Islam is the only way out". Political Islamist organizations emphasized the injustice of the political order in the existing world, stressing that the Muslim community was being bullied and repressed. It advocated emulating the practice of the Prophet Muhammad in Medina by replacing the existing world order with a new world order. Shari a is the only law. Muslims must accept the standard of "true Islam", or they will be labeled as "pseudo-believers" and "enemies of Allah." 


\subsection{National Identity could not Replace Religious Identity}

In the early 20th century, under the impact of nationalism, Islam appeared to be under the national and state conditions, and its political color was diluted. At that time, the countries that believed in Islamic religion have embarked on the national-state road of construction one after another. Religion, which has long existed and was often linked with the old rulers, was considered as one of the causes of the decline of the poor. Nationalists represented by intellectuals turned to the question of how the West is affluent and powerful, so religion was no longer important adhesive in the establishment of a new state. Islam in this period seemed to recede in the political life. The rise of non-religious modern social ideology has become the spiritual manifestation of the emerging political forces and was widely recognized by the public opinion in the society. After the reform of legal and social system, Islamic dominance in the two major fields of justice and education no longer existed. With the establishment of an independent state under the banner of nationalism, religions tended to be at the second place in the construction of the modern state. Therefore, it appeared that Islam had faded out of the political sphere. There were three types of relationship between the state and religion in the post-Mideast countries. Except for Turkey whose political model was the separation of religion and state and Saudi Arabia whose political model was unification of religion and state, most of the countries belonged to the type of intermediary. On the one hand, these countries affirmed the important status of Islam in the constitution, including stipulating Islam as a state religion, the heads of state that must be Muslim, and Islamic law as one of the origins of the legislation. On the other hand, the official ideology, the national political system, the party organizations, the parliamentary system, the role of political leadership, etc. were based on secularization as the fundamental direction. However, with the further development of these independent Islamic countries and regions, people found it impossible to replace religion with nationalism. National identity could not replace religious identity. More importantly, the nation-state did not lead people onto the path of affluence. In the context of social structural changes, Muslims were deeply vulnerable and unsafe. Meanwhile, they were eager to find collective identity and seek to change the realistic dilemma. Islam just had the function of both spiritual comfort and economic help, so they used Islam to express dissatisfaction and demands.

\subsection{The Political Internationalization of Islam in the Late $20^{\text {th }}$ Century was the Inevitable Result of Globalization}

The 20thcentury was a century of globalization. Globalization was a continuous process of inequality. After the end of World War II, the two major political camps emerged from confrontation to the dissolution of a large camp. As a result, the state appeared more and more as a unitary entity in international community. The western powers led by the United States promoted power politics and infringed on the interests of Muslim peoples. The Middle East issue was largely linked to the behind-the-scenes economic interests of the western world. When intervening in the internal affairs of the Middle East, the western world imposed its own religion and culture on the Middle East. This control and penetration will inevitably lead to anti-control and reverse osmosis.

\section{The Influence of Changes of relations between Islam and Politics in 20th Century on the Strategy of Belt and Road in China}

In the 21 st century, the imbalance in the development of science and technology has exacerbated the differences in the development forces among different countries. Such differences have been demonstrated inexplicably through the economic, cultural and even religious conflicts. The development space and opportunities have become one of the important goals of all countries. The integration of network technologies and markets has made it impossible for individual country to enhance its international competitiveness through closed self-development. The de velopment strategy of "One Belt and One Road" proposed by China offers both opportunities and possibilities for the cooperation and development within Asia and beyond. However, it also faces the challenges caused by the differences in economy, culture and especially religious concepts.

\subsection{The tendency of National Political Islam Complicates Economic, Religious and Political Issues}

Political Islam performs differently in different regions of the Muslim world, such as the Muslim Brotherhood in Egypt, Hezbollah in Lebanon, the Dawa Party in Pakistan, Jamaya in Indonesia, Al Qaeda and Izabet, etc. Political Islam and Islamic politics have different political meanings. The former extensively mobilized the religious identity of Muslims so that religion and politics would be closely tied together. Religion is politics and politics is also religion. Politics and religion in the latter are in the relationship under the condition of separation and independence from each other. Political Islam is a reflection of the mistrust of Western liberal democracy. Religions and various forms of nationalism have become tools of fighting for interests and safeguarding their rights, eventually they led a series of regional conflicts: the Gulf War, the Bosnian war, the Somali civil war, the Tajik civil war and the Afghan civil war. All these problems will make it more difficult for China to carry out this strategy. 


\subsection{Pan-Islamism Complicates and Destabilizes Relations among Nations along the Line}

The relations among the countries along the Belt and Road strategy are complicated and changeable. For example, after the founding of Pakistan, the Jinnah and the Muslim Alliance wanted to embed Islam within the national system, while Mautdudi and the "Association of Islamic Theologians" he founded wanted the re-sanctification of political life and the inclusion of the country and the citizenry within Islam. As a convening banner, Islam brings all believers together in the same religious identity. Some extremists advocate "Islamist nationalism" and "Pan-Islamism" and the export of Islamic revolution, and e ven resort to terrorist violence as a means to achieve their own goals. This makes it necessary for China to exercise cautiously and carefully in implementing this strategy. Therefore, when implementing the strategy of the Belt and One Road, it is necessary for China to study these issues such as the religious, political and ethnic relations of related countries, the religious sectarian conflicts, the status of religious extremists and the latitude of religious ris ks so as to reduce the occurrence of religious risks. Since Islam is not inherently political in nature, with economic development, globalization of immigrants, popularization of science education and changes in concept, Islam will eventually return to religion itself.

\section{References}

Huang, P. (2017). Religious Risks in the "Belt and Road Initiatives" - Taking Pakistan as an Example. Journal of Shanghai Jiaotong University (Philosophy and Social Sciences), 25(3), 14-22.

Lirong, M. (2015). "The Belt and Road" and "Religious Factors" in the Strategic Cooperation between Asia and Africa. West Asia and Africa, 236(4), 4-20.

Liu, Y. (2017).Religious Risks in Turkey under the Belt the Road. The World Religious Cultures, 106(04), 8-15.

Xiaoyun, Z. (2016). Research on the Belt and a Road Strategy and Religious Risk - Based on Possibility and Necessity .Studies in World Religions, 162(06), 27-41.

Xinping, Z. (2015). Religious Historical Accumulation and Realistic Situation on the "Belt and Road Initiatives". China Religion, 187(6), 30-31.

Xuemei, Q. (2009). Political Islam Ideology and Politics of Islam. West Asia and Africa, 190(2), 24-30.

Yang, L. (2017). Research on the Religious Risk in Kazakhstan in the Belt and Road Strategy Implementation. The World Religious Cultures, 104(02), 31-37.

Yun, L. (1999). Islam and the Political Modernization of Turkey. West Asia and Africa, 115(2), 41-46.

\section{Copyrights}

Copyright for this article is retained by the author(s), with first publication rights granted to the journal.

This is an open-access article distributed under the terms and conditions of the Creative Commons Attribution license which permits unrestricted use, distribution, and reproduction in any medium, provided the original work is properly cited. 